\title{
DECISÃO DO HABEAS CORPUS N. 126.292: RELATIVIZAÇÃO DO PRINCÍPIO DA PRESUNÇÃO DA INOCÊNCIA E JURISDIÇÃO CONSTITUCIONAL EM PERSPECTIVA
}

\author{
DECISION OF HABEAS CORPUS N. 126.292: RELATIVIZATION OF THE \\ PRINCIPLE OF PRESUMPTION OF INNOCENCE AND THE CONSTITUTIONAL \\ JURISDICTION IN PERSPECTIVE
}

\author{
${ }^{1}$ Hamilton da Cunha Iribure Júnior
}

2 Jefferson Prado Sifuentes

\section{RESUMO}

O artigo tem por objetivo analisar a quebra da presunção de inocência com a antecipação do cumprimento da pena, antes do trânsito em julgado da sentença condenatória, em recente decisão do Supremo Tribunal Federal. Adotada metodologia analítica documental. Parte da premissa que os Direitos Fundamentais não são absolutos e que devem ser relativizados. Aborda-se a jurisdição constitucional nessa perspectiva e os limites da atuação do judiciário no exercício da interpretação da lei. Uma das conclusões é a de que a relativização de direitos fundamentais no Brasil segue tendência de se dar em instância que não seja a da Corte Constitucional.

Palavras-chave: Inocência, Relativização, Legitimidade, Constituição

\begin{abstract}
The article aims to analyze the breach of the presumption of innocence with the anticipation of the sentence before the final judgment of conviction, in a recent decision of the Supreme Court. Adopted documentary analytical methodology. Assumes that fundamental rights are not absolute and must be relativized. Deals with the constitutional jurisdiction in this perspective and the limits of the judicial role in the exercise of interpretation of the law. One of the conclusions is that the relativization of fundamental rights in Brazil follows tendency to give in proceedings other than the Constitutional Court.
\end{abstract}

Keywords: Innocence, Relativization, Legitimacy, Constitution

\footnotetext{
${ }^{1}$ Doutor e Mestre em Direito pela Pontifícia Universidade Católica, PUC - SP, (Brasil). Docente da Graduação e do Programa de Mestrado da Faculdade de Direito do Sul de Minas, FDSM -MG, (Brasil).

E-mail: hamilton.adv@terra.com.br

${ }^{2}$ Mestrando em Direito pela Faculdade de Direito do Sul de Minas, FDSM - MG, (Brasil).

E-mail: sifuentesjefferson@gmail.com
} 


\section{INTRODUÇÃO}

A História do desenvolvimento humano sempre fora analisada sob o ângulo das atividades que o indivíduo exerce em sociedade. Desta atividade, surgem os conflitos, os confrontos entre grupos determinados dentro do mesmo território e, até mesmo, em territórios distintos.

As atividades humanas, de plano, podem ser analisadas sob o prisma de sua exteriorização, esta que, por sua vez, ocorre com relação aos seus semelhantes ou de acordo com sua ação sobre os bens, materiais ou imateriais que lhe proporcionam os recursos de conservação e de desenvolvimento.

Em análise inicial, o direito deve sempre pressupor a existência do indivíduo e da atividade por ele exercida quando em vivência social. A finalidade primordial a ser invocada é a própria coexistência do ser. Há uma inegável tendência a invocar o direito como um conjunto de parâmetros que em sua essência destina-se a proteger e a aperfeiçoar o indivíduo. Para tanto, não pode o indivíduo ser considerado isolado.

A Constituição da República de 1988 consagra o princípio da presunção da inocência ao cravar que ninguém será considerado culpado até o transito em julgado de sentença condenatória. Tal cenário aborda a possibilidade de o réu ter o direito de recorrer às instâncias superiores para apreciar a circunstância jurídica. Infere-se aqui, uma nítida questão que cerca a dignidade humana e a presunção de inocência, devendo-se aferir uma proteção do indivíduo contra um Estado punitivo.

Deste modo, a restrição à liberdade, penalidade máxima prevista na órbita jurídica brasileira em tempos de paz, somente será iniciada esgotado todos os recursos, com o posicionamento definitivo dos tribunais, o que, apesar de ser plenamente constitucional, deixa transparecer para a sociedade ares de impunidade devido ao tramite do devido processo legal, tido como lento.

Neste prisma, objetiva-se apreciar a questão da antecipação da pena para após a chancela de segunda instância, tal como adotado pela Suprema Corte na oportunidade do julgamento do Habeas Corpus n. 126.292 e impacto de redução da impunidade que tal entendimento pode causar. Contudo não se pode olvidar da dignidade da pessoa humana e dos aspectos da jurisdição constitucional. 
Definidos a problematização e os objetivos nucleares, acima descritos, o presente trabalho, ao analisar os quadrantes que envolvem a presunção de inocência sendo relativizada, com a via recursal ainda aberta, emprega a metodologia de pesquisa analítica documental.

\section{JUSTIÇA E IMPUNIDADE: CONSTATAÇÃO DOS CONTORNOS DA ETERNA LINHA DE CONFLITOS}

A Fundação Getúlio Vargas (FGV) instituiu o Índice de Confiança na Justiça Brasileira, critério indexador do índice ICJBrasil. Tal índice é elaborado com base em pesquisas nas quais se busca a opinião da população brasileira quanto à atuação do Poder Judiciário e o grau de satisfação neste.

A pesquisa realizada durante o ano de 2014 pautou-se por amostragem na qual foram entrevistados 6.623 pessoas, ao longo de 7 (sete) Estados brasileiros, além do Distrito Federal, que, representam todas as regiões do Brasil. Amazonas, Pernambuco, Bahia, Minas Gerais, Rio de Janeiro, São Paulo, Rio Grande do Sul e Distrito Federal, que juntos, segundo dados do censo 2010 (IBGE) representam aproximadamente 55\% da população brasileira, foram as unidades da Federação objeto da citada pesquisa.

Para conduzir um viés de heterogeneidade aos dados, a pesquisa fundou-se num método de

\footnotetext{
seleção amostral não probabilística denominado amostragem por cotas, considerando-se as seguintes variáveis de controle de cotas: sexo, rendimento mensal domiciliar, escolaridade, faixa etária e condição econômica (indivíduo economicamente ativo ou não). Dessa forma, um determinado número de entrevistas foi estabelecido para cada uma das categorias dessas variáveis e procurou-se entrevistar pessoas pertencentes à população-alvo até atingir-se tal número de entrevistas em cada cota.

As cotas foram distribuídas proporcionalmente à população segundo os dados Do Censo 2010 e da PNAD (Pesquisa Nacional por Amostra de Domicílios - do IBGE) 2009. Além do controle de cotas de tais variáveis econômico-demográficas, controlouse também a mesorregião do Estado, distribuindo-se as entrevistas proporcionalmente segundo dados do Censo 2010 (ICJBrasil, 2014, p. 06).
}

O resultado do sexto ano da pesquisa aponta dados relevantes e que merecem reflexões na órbita jurídica. Ao fim de 2014, segundo dados da pesquisa, apenas $31 \%$ dos entrevistados declarou confiar no Poder Judicante, sendo que este índice de confiança chegou a $26 \%$ no segundo trimestre daquele ano (ICJBrasil, 2014, p. 13). 
Significativos $88 \%$ dos participantes da amostragem concordam que o Poder Judiciário presta um serviço lento. Além da demora para a solução dos litígios, outros dados representam muita insatisfação da população para com o judiciário (ICJBrasil, 2014, p. 13).

Dos entrevistados, 64\% considera o Poder Judiciário pouco ou nada honesto, enquanto que 56\% afirma que este Poder é pouco ou nada competente (ICJBrasil, 2014, p. 13). Além do mais, cerca de $61 \%$ dos entrevistados não acredita na independência do Poder Judiciário. Cappelletti e Garth (1988, p. 9) trazem ainda que procedimentos complicados, formalismo, ambiente que intimida, como o dos tribunais, juízes e advogados, figuras tidas como opressoras, fazem com que o litigante se sinta perdido, um prisioneiro num mundo estranho.

Desta maneira, os dados obtidos no sexto ano do Índice de Confiança na Justiça, "seguem a tendência, já identificada nos relatórios anteriores, de má avaliação do Judiciário como prestador de serviço público" (ICJBrasil, 2014, p. 13).

Ressalte-se que o Judiciário ocupa posição desprivilegiada frente à outras instituições objeto da pesquisa, tangencialmente à ser credor da confiança popular. Das 11 instituições avaliadas, o judiciário ocupa apenas a oitava posição dentre as mais confiáveis. A pesquisa do sexto ano do ICJBrasil demonstrou que a população brasileira confia mais em Emissoras de Televisão, a Polícia, as Grandes Empresas, a Imprensa Escrita, o Ministério Público, a Igreja Católica e as Forças Armadas do que no Poder judiciário.

A insatisfação da população para com o Poder Judiciário, conforme ilustrado pelo índice ICJBrasil, além da lentidão na prestação dos serviços, pode estar relacionada com a impunidade ou com a sensação desta, que insiste em perturbar a população brasileira. Conforme dados trazidos por Gomes (2012), apenas cerca de 5\% a 8\% dos casos de homicídio são elucidados no Brasil, concluindo que o país ostenta o rótulo da impunidade (GOMES, 2012, p. 28-29).

Diante de tal perspectiva, propõe análise de outra pesquisa da Fundação Getúlio Vargas, segundo a qual o percentual de $81 \%$ dos brasileiros concorda que é fácil desobedecer às leis, enquanto que a taxa de $57 \%$ da população nacional considera que há poucos motivos para que as leis sejam obedecidas no Brasil.

Diante de tais cenários, o Brasil possui um elevado índice de impunidade, que certamente contribui para a insatisfação da população para com o judiciário, demonstrada pela pesquisa do Índice de Confiança na Justiça - ICJBrasil.

Tais números foram levantados para ilustrar o cenário brasileiro e convidar o leitor a refletir acerca do tema. De fato, os ditames constitucionais que banham a órbita processual 
penal, vislumbram o princípio da presunção da inocência, segundo o qual, ninguém será considerado culpado até o trânsito em julgado de sentença penal condenatória.

O regular tramite do devido processo legal, até uma eventual condenação, a pena privativa de liberdade e a execução desta, pode demorar perante os olhos da população, sedentos por "justiça" - na concepção popular da palavra -mediante o cometimento de um crime, o que acaba gerando uma imagem ruim do judiciário, conforme traduzido numericamente pelas pesquisas da Fundação Getúlio Vargas.

A penalidade que provoca anseios na sociedade, possui contornos de "um freio contra o crime, representando, um indireto contramotivo aos possíveis criminosos de amanhã" (HUNGRIA, 1940, p. 132), objetivando, num curto prazo, alcançar a paz interna (GÜNTHER, 2008, p. 19), a fim de evitar que a sociedade mergulhe no caos, sendo motivos sensíveis para tanto (BECCARIA, 2002, p. 20).

A pena aqui delineada, objetiva ainda, demonstrar a eficácia da norma às custas de um responsável, tendo por escopo, a manutenção da norma enquanto paradigma norteador de contatos sociais (GÜNTHER, 2008, p. 21-27). Nesta concepção, a falta de pena, traduz-se numa ineficácia normativa e deixa leves reflexos de incompetência estatal, pautada na impunidade, gerando, como de fato fora demonstrado, insatisfação na população. No entanto, deve-se refletir acerca Poder Judiciário ser o responsável sociológico pela sensação de impunidade que insiste em assombrar a população.

\section{A PRESUNÇÃO DA INOCÊNCIA NUMA MUDANÇA HERMENÊUTICA HISTÓRICA NO STF}

Nos horizontes dessa perspectiva, um notável corte epistemológico foi realizado pelo Supremo Tribunal Federal, na oportunidade do julgamento do Habeas Corpus n. 126.292, mudança de rumo, esta, que colaciona impactos sensíveis à relativização principiológica de preceitos fundamentais no Brasil.

Decidiu o Pretório Excelso que se uma condenação criminal, em primeira instância, for mantida em sede recursal direta, estará apta a produzir seus efeitos para que seja, no caso, determinado o imediato cumprimento da pena, ainda que tal decisão seja passível de recursos em outras instâncias.

Tal decisão histórica e impactante no ordenamento jurídico modifica a jurisprudência da Suprema Corte, até então havida e consagrada por força do julgamento do Habeas Corpus 
n. 84.078/MG, a qual se estabilizava no sentido de que somente com o trânsito em julgado de sentença penal condenatória, se legitimaria qualquer cumprimento de pena em definitivo. Ao que tudo indica, tal entendimento se perfilava com os horizontes esquadrinhados pela Constituição da República de 1988, esta que verbaliza, textualmente, a presunção de inocência como direito/garantia fundamental do indivíduo nos quadrantes democráticos da República brasileira.

Pelo texto Maior, por deveras, ninguém pode ser considerado culpado até o trânsito em julgado de sentença penal condenatória, sendo tal premissa a estampa do inciso LVII, ínsita no bojo do artigo $5^{\circ}$., da Carta Política de 1988. Só para registro, texto com natureza de cláusula de imodificabilidade constitucional.

Desta maneira louva-se a máxima que todos são inocentes até que se provem o contrário. E essa oração "até que se provem o contrário" abrange não só a gama probatória a ser produzida, apta a quebrar aludida presunção, mas também, sobretudo, os meios inerentes à defesa, ou ampla defesa do denunciado, buscando não só a presunção, mas, a certeza de inocência. Vislumbra-se, pois, todos os esclarecimentos necessários, mediante análise probatória, objetivando-se a busca pela verdade real.

Se o inovador entendimento da Suprema Corte no julgamento do HC n. 126.292 for mantido, a execução de pena dar-se-á após sentença condenatória confirmada pelas duas primeiras instancias, não obstante a pendências de recursos, o que será analisado adiante.

A antecipação do cumprimento da pena seria instrumento hábil a reduzir o índice de impunidade? Talvez. O que transmitiria uma impressão de que a justiça foi alcançada, passando o Judiciário à população uma sensação de segurança, além de aumentar a credibilidade da sociedade nas instâncias judiciais.

Mas, partindo para outra reflexão, a instituição de políticas para a concretização da segurança pública compete ao judiciário? Questão relevante, a qual se propõe análise conjunta com a reflexão acerca da atuação do Judiciário com viés ativista e de judicialização da política. 


\section{A DECISÃO DO STF NA ANGULAÇÃO DO CONSTITUCIONALISMO CONTEMPORÂNEO}

Os dados aqui colacionados, além da frieza algébrica que eles possam representar, carecem de análise. Foi concluído que apenas $31 \%$ confia no Poder Judiciário. Tal dado, interpretado em consonância com o fato de que $81 \%$ da população acredita ser "fácil desobedecer leis no Brasil", aliado, ainda, à representatividade de 57\% da população que acredita que não há motivos para seguir as leis, coloca em cheque toda a estrutura jurídicopolítica vigente no país, ou, minimamente, nos remete a uma profunda meditação.

Pois bem, o julgamento do Habeas Corpus n. 126.292 adentra num mérito de relevo na órbita jurídica e que desperta a preocupação e, por conseguinte, a descrença da sociedade no tridente político brasileiro: a impunidade.

A recente decisão da Suprema Corte brasileira, enfrenta a impunidade, ou a sensação desta, conferindo certa saciedade à população no que tange à atuação jurisdicional, conferindo aos jurisdicionados, ares da almejada segurança pública.

As questões às quais o Judiciário é convidado a apreciar, não traduzem apenas e tão somente em ditames puramente jurídicos. A Suprema Corte, com a honraria de guardião da Constituição, é desafiada diariamente a desvendar embaraços jurídicos com a missão quase impossível de propor solução que almeja a busca, num horizonte quase utópico, pela pacificação social.

Contudo, os impactos da judicialidade são suportados pela sociedade, aliás, o direito foi feito para servir a esta. Ressalta-se ainda que a sociedade necessita visualizar o macro direito para a regulação de suas atividades quotidianas.

Foi destacado ainda, pelo índice de Confiança na Justiça, levantado pela Fundação Getúlio Vargas, que, apesar da baixa credibilidade popular que goza o Poder Judiciário, este ainda, segundo dados do IJCBrasil, é mais confiável que o Congresso Nacional e o Governo Federal, representantes em âmbito federal, dos poderes Legislativo e Executivo. O que demonstra o preocupante cenário que nenhum dos poderes da República são dignos da crença popular.

Neste aspecto, há que se ressaltar, contudo, que, mesmo com a baixa credibilidade suportada pelo Judiciário, este é acionado para a satisfação de um direito ou busca pela cessação de uma ameaça, o que faz louvar o acesso à justiça, conforme adotado na seara constitucional. 
Com o escopo de assegurar direitos e garantias, a Constituição da República vigente carrega em seu bojo que a lei não excluirá da apreciação do Poder Judiciário lesão ou ameaça a direito, vislumbrando deste modo o princípio da inafastabilidade da jurisdição, consagrando o direito de ação.

Nos moldes da Constituição da República de 1988, aquele que tiver um direito lesado ou mesmo ameaçado poderá submeter à análise do Poder Judiciário, exercendo este poder importante função à concretização de direitos vislumbrando o acesso à justiça.

Em que pese os direitos e garantias fundamentais terem aplicabilidade imediata, nos exatos termos do $\operatorname{artigo} 5^{\circ}$., $\S 1^{\circ}$. da Constituição da República de 1988 , eles não são autoaplicáveis por conter previsão constitucional, tornando-se necessário a atuação jurisdicional visando a plena eficácia.

Assim, o acesso à jurisdição se trata de importante instrumento à disposição do cidadão, o qual visa à efetivação de direitos constitucionalmente assegurados que são lesados e ameaçados, inclusive para garantia da regularidade, encarregada de anular atos irregulares (KELSEN, 2003, p. 108). Assegurar a garantia de tais direitos (humanos) reflete um dos preceitos da nação democrática e humanitária que se tornou o Brasil.

É através da jurisdição que se busca a efetividade de direitos previstos em sede constitucional. Não fosse a jurisdição constitucional e o direito de ação, consagrado pelo princípio da inafastabilidade da jurisdição, a Constituição dirigente certamente estaria morta ou no mínimo em estado vegetativo. Há de se ressaltar que "a jurisdição constitucional serve primordialmente para a preservação da constituição" (ABBOUD, 2011, p. 101) e "aprimoramento da vida democrática e manutenção da tranquilidade social" (COELHO, 2009, p. 166).

Desse modo, o acesso à jurisdição reveste-se de um importante mecanismo posto à disposição do cidadão para efetivação de direitos constitucionalmente assegurados que venham a sofrer lesão ou ameaça no exercício da vida. Logicamente, que nada adianta a aludida previsão se for ela desprovida de efetividade. Nesse sentido, "a jurisdição constitucional passou a ser crescentemente considerada como elemento necessário da própria definiçãa do Estado de Direito Democrático" (STRECK, 2014, p.115).

A tempo de um rasteiro registro sobre a jurisdição constitucional é de bom alvitre anotar que tal 
(...) emergiu historicamente como um instrumento de defesa da Constituição, não da constituição considerada como um puro nome, mas da Constituição tida como expressão de valores sociais e políticos. Essa é uma questão fundamental, que se coloca em resposta aos tipos de ataques que a Constituição pode sofrer, surgindo disso, dois sistemas: o norte Americano e o Europeu. O norte-americano gerou um sistema, fundado no critério difuso, de natureza técnico-jurídica, a ponto de afirmar- se que não se caracteriza verdadeiramente como uma forma uma forma de jurisdição constitucional, não tanto por ter sido entregue o controle de constitucionalidade à jurisdição ordinária, mas pelo fato de que a jurisdição ordinária não aprecia a Constituição em função de seus valores políticos, não se configurando como guardiã dos valores constitucionais, por ter como objetivo principal a decisão do caso concreto. Entendemos que também aí existe jurisdição constitucional, tomada a expressão no sentido de modo a compor os litígios constitucionais. Apenas não se realiza com plenitude a função de guarda dos valores constitucionais, dada a preferência pela decisão do caso concreto. O sistema europeu desenvolveu-se como resposta aos ataques político e ideológico da Constituição. O sistema de defesa não poderia ser senão de natureza política e ideológica. A evolução chegou à evolução das Cortes Constitucionais, a partir de 1920 , como os únicos tribunais competentes para solucionar conflitos constitucionais, fundado no critério de controle concentrado (SILVA, 2015, p. 563-564).

Diante do cenário do atual acesso à tutela jurisdicional, tal como previsto na Constituição da República, aliado à falta de confiança que os Poderes Legislativo e Executivo, suportam perante a população, nota-se que esta se encontra tendente a migrar para o Judiciário, almejando a solução de determinada problemática social.

Assim, como no julgamento do HC n. 126.292, a Suprema Corte tem sido frequentemente convocada a apreciar questões jurídico-sociais, exercendo, por conseguinte, um papel ativo na vida institucional brasileira (BARROSO, 2012, p. 23). Desse modo, há de se notar certo protagonismo judiciário, onde este Poder, em muitas oportunidades, assume a responsabilidade de desenvolver soluções "extrajurídicas", mas que atendam, por outro lado, também, às expectativas da sociedade. Ilustra tal imigração ao judiciário, o crescente número de ações pleiteando medicamentos e tratamentos terapêuticos.

Uma pesquisa realizada pelo Conselho Nacional de Justiça (PEREZ, 2015, p. 04-06) mostra que entre 2011 e 2014, o número de ações de tal natureza em trâmite perante o judiciário brasileiro cresceu em 63\%, sendo 241 mil processos em 2011 e por volta de 393 mil demandas no ano de 2014. Tais dados ilustram a maior participação do Órgão Judiciário, traduzindo em números a judicialização enfrentada hodiernamente, com o viés de instituidor de políticas públicas recaindo sobre os ombros do judiciário.

Na oportunidade do julgamento do Habeas Corpus n. 126.292, novamente a Suprema Corte foi desafiada a tratar de uma questão, que, além do caráter jurídico, produz reflexos na seara social, causando a decisão desta alta Casa de Justiça, sombras de políticas públicas para cercear a impunidade e reforçar a segurança pública. 
A decisão do Supremo Tribunal em antecipar o cumprimento da pena em caso de condenação confirmada em segunda instância, pode ser interpretada como um importante ato contra a impunidade, com ventos de satisfação aos jurisdicionados. Talvez esse seja o nódulo ao qual convergem as expectativas no presente trabalho. Em outras (e singelas) palavras, identificar se o cabe à Corte Maior do país atuar, abreviando a via recursal para obrigar o cumprimento de uma pena, ainda sem trânsito final atingido. Seria uma pequena amostra de agrado à população para ocultar algo de maior complexidade?

Certamente, para a realidade democrática contemporânea, louva-se um Poder Judiciário forte e atuante para coibir eventuais abusos referentes aos independentes poderes legislativo e executivo, vislumbrando uma democratização. Nesse talante o Poder Judiciário torna-se uma verdadeira força concreta (NAGEL, 2009, p. 162) a fim de assegurar e efetivar direitos e garantias, contemplados na Carta Política, propondo um diálogo constitucional entre a Corte e outras agências do governo, numa sutil dialética interação de temas morais (NAGEL, 2009, p. 174).

A própria atuação jurisdicional possui a grande tarefa de:

\begin{abstract}
instrumentalizar a função primordial do próprio constitucionalismo, qual seja, coibir os excessos do poder público. Nas palavras de Peter Härbele, a função da jurisdição constitucional consiste na limitação, racionalização, e controle do poder estatal e social, na proteção das minorias e os débeis e na reparação dos novos perigos para a dignidade humana. Konrad Hesse enaltece que a jurisdição constitucional em última sede assegura a preservação do direito bem como possibilita o controle judicial amplo do Poder Executivo, em concreto a atividade da Administração Pública. É principalmente, por meio da jurisdição constitucional que o Poder Judicial insere-se, hoje, no equilíbrio dos poderes. A tarefa da jurisdição constitucional é decidir com autoridade, os casos de violação ao texto constitucional. Essa atividade inclui tanto o controle dos poderes estatais como tarefa da concretização e evolução do direito constitucional. Imperioso ressaltar que essa tarefa, principalmente no Brasil, não se restringe apenas à jurisdição constitucional (ABBOUD, 2011, p. 101).
\end{abstract}

Da mais valia feita, há de se ressaltar que os poderes do Estado são independentes, sendo que a cada um compete o exercício de suas funções. Não se pode olvidar, entretanto, que entre os poderes coexiste uma harmonia recíproca, pois, ao isolar completamente os poderes do controle político, pode haver uma privação do processo democrático de seu significado central (ACKERMAN, 2014, p. 18). 
Assim,

\begin{abstract}
a idéia da repartição do poder entre vários órgãos, antes para que se controlem uns aos outros do que para isolá-los uns dos outros. Isso, não apenas para impedir excessiva concentração de poderes nas mãos de determinado órgão - o que ameaçaria a democracia - como também para assegurar a regularidade do funcionamento dos diversos órgãos. Com isso, o instituto da justiça constitucional não contradiz, em absoluto, o princípio de separação dos poderes, sendo pelo contrário uma afirmação dele (KELSEN, 2003, p. 109).
\end{abstract}

Em que pese a interdependência harmônica e a sua função ímpar na democratização do Estado, não cabe ao Judiciário, moldar, a cada sentença os problemas sociais a fim de ser o "salvador da nação" a todo custo. Cabe sim, abordar a problemática, contudo, dentro dos limites constitucionais e, sobretudo, respeitando os poderes do Estado.

A decisão proferida pela Suprema Corte, no julgamento no Habeas Corpus n. 126.292, se propõe, de fato, a enfrentar uma questão de plena consequência perante a sociedade, que objetiva viver em segurança. Acontece que, as decisões judiciais, mesmo que atendam aos anseios da sociedade, não podem desvirtuar preceitos constitucionais, sob risco de ofensa ao sistema democrático, na via inversa.

A Carta constitucional vigente, a teor do artigo 144, caput, estabelece que a segurança pública é dever do Estado, sendo exercida para a preservação da ordem pública e da incolumidade das pessoas e do patrimônio, sendo garantida por órgãos policiais.

Neste cenário, propõem-se analisar a decisão da Suprema Corte, no julgamento do Habeas Corpus n. 126.292, sob o prisma do fenômeno da judicialização, sendo decorrente do acesso à jurisdição, o qual há de ser diferenciada de conduta ativista. Esta, pode causar bastante desconforto devido ao protagonismo do judiciário.

Os fenômenos do ativismo e judicialização são "primos, vêm, portanto, da mesma família, frequentam os mesmos lugares, mas não têm as mesmas origens" (Barroso, 2012, p. 25). Em tal seara, os reflexos da própria atuação do Poder Judiciário vão determinar o grau da conduta, dentro da constitucionalização.

No tocante ao fenômeno ativista, o protagonismo exercido pelo judiciário se faz eclodir observando algumas condutas, tais quais: 
a aplicação direta da Constituição a situações não expressamente contempladas em seu texto e independentemente de manifestação do legislador ordinário; (b) a declaração de inconstitucionalidade de atos normativos emanados do legislador, com base em critérios menos rígidos que os de patente e ostensiva violação da Constituição; (c) a imposição de condutas ou de abstenções ao Poder Público, notadamente em matéria de políticas públicas (BARROSO, 2012, p. 26).

No que tange à proposta desafiada ao Supremo Tribunal, no Habeas Corpus n. 126.292, esta Excelsa Corte, muda o entendimento até então fixado no HC n. 84.078, que, à luz da Constituição da República de 1988, firmava o entendimento que o cumprimento de eventual pena, dar-se-á quando não mais, há possibilidade de interposição de recursos, mediante o trânsito em julgado de sentença penal condenatória.

O novo posicionamento ora explanado, cria regras alheias ao texto constitucional, adotando novas possibilidades normativas, o qual extrapola a conduta tecnicamente jurisdicional que compete ao órgão judicante, traduzindo-se num perigoso ativismo, que passa a conferir ventos de cunho legiferantes às decisões do Poder judicante.

O que se nota, é que o Poder Judiciário segue adotando certos tons normativos, ao citar como exemplo, o Tribunal Superior Eleitoral, que, ao editar, por exemplo, a resolução n. 22.610, em 25 de outubro de 2007, passou a estabelecer casos de infidelidade partidária, alheias aos previstos em sede constitucional. Adota a referida resolução que independente de justa causa, pode haver decretação da perda do cargo eletivo devido a ocorrência de desfiliação partidária, criando, hipótese de perda de mandato eletivo.

Importante resgatar o texto constitucional (artigo 15), que prevê hipóteses de perda de direitos políticos em caso de cancelamento da naturalização com sentença transitada em julgado, incapacidade civil absoluta, condenação criminal transitada em julgado, enquanto durarem seus efeitos, recusa em cumprir obrigação a todos imposta ou prestação alternativa e improbidade administrativa, o qual foi interpretado de modo extensivo pelo órgão judicante eleitoral.

Tal situação conduz um viés ativista que vem se agregando à personalidade (e composição) da Suprema Corte nacional, que por vezes avoca o caráter de guardião moral da Nação, podendo concluir-se, portanto, 
que a deferência do Pretório Excelso, quanto à criação pelo TSE de regras de reflexos diretos no arranjo político, traduz-se numa adição de conteúdo que desborda da possibilidade reconhecida e necessária da atribuição de sentido, indo além de sua função de mediador ou impulsionador das discussões públicas (OLIVEIRA, 2014, p. $133)$.

Nessa esteira, como a atuação judicante abordada na presente resolução do TSE, nota-se também, atuação extensiva da Suprema Corte ao estabelecer o início de cumprimento da pena tão logo sobrevenha condenação em segunda instância, dando nova concepção até mesmo ao texto constitucional. Percebe-se o caráter de guardião moral da nação, adotado neste caso, tendente fechar a janela da impunidade.

Gloriosamente há que se destacar que a interdependência harmônica deve reinar perante os poderes, com o claro limite a atuação de cada um, sendo, de relevância absurda para o Estado democrático a atuação do Judiciário, dentro, contudo, dos parâmetros constitucionais.

\section{RELATIVIZAÇÃO DE PRINCÍPIOS: A INOCÊNCIA EM XEQUE}

O julgamento do Habeas Corpus n. 126.292, objeto do corte espistemológico e interpretativo, afia diretamente o princípio da presunção da inocência, previsto em sede Constitucional, que a teor do artigo $5^{\circ}$., inciso LVII, da Carta Maior de 1988, estabelece que ninguém será considerado culpado até o trânsito em julgado de sentença penal condenatória. Mendes (2009, p. 676), refere-se a tal princípio ainda como "princípio da não culpabilidade", nomenclatura também usual no ordenamento pátrio.

O princípio da presunção da inocência possui impacto marcante para a evolução dos direitos humanos ao curso da história. Diversas Cartas sobre direitos fundamentais e humanização de direitos tratam da presunção de inocência do mundo todo. A Declaração Universal dos direitos do Homem e do Cidadão, Carta Parisiense para o mundo, em 1789 (artigo $\left.9^{\circ}.\right)$, por exemplo.

Ainda, citam-se o Pacto assinado em San Jose, na Costa Rica, chancelada como Convenção Americana de Direitos Humanos de 1969 (artigo 8.2), a Declaração Universal dos Direitos Humanos de 1948 (artigo XI) - Carta do pós-guerra - e as versões consolidadas do tratado da União Europeia, além do tratado sobre funcionamento da União europeia com a carta de direitos fundamentais da União Europeia (artigo 48 ). 
Todos os mencionados diplomas, a título de rasteiros exemplos, abordam o preceito da presunção de inocência, temática nuclear e principiológica do vertente trabalho, sempre no quesito de se garantir a inocência de qualquer indivíduo até que se prove o contrário e que se esgote a última instância recursal, proporcionando a ele todos os meios inerentes para o exercício de sua defesa e a atenção ao curso regular do devido processo legal.

$\mathrm{O}$ desdobramento do princípio em comento "impede a outorga de consequências judiciais sobre o investigado ou denunciado antes do transito em julgado de sentença criminal" (MENDES, 2009, p. 678). Diga-se, numa análise mais ousada, da certeza iuris tantum da inocência de qualquer pessoa.

Inocência esta, suscetível de prova em contrário e de desconstituição para, somente com o transito em julgado de sentença criminal, poder-se decretar a culpabilidade de alguém. A regra é o tratamento da pessoa como inocente e não como "semiculpada" ou "presumivelmente" culpada (GIACOMOLLI, 2013, P. 445). Assim,

o que não se pode inferir da presunção de inocência, em primeiro lugar, é que não pode haver inversão do ônus da prova, se ao Poder público compete o formalizar a denúncia, também cabe-lhe promover as provas necessárias, assegurados, o contraditório e ampla defesa" (BASTOS; MARTINS, 1989, p. 278).

A questão envolvendo a principiologia da presunção da inocência, interpretado em consonância com o cumprimento de pena privativa de liberdade, mais precisamente, o momento do início da custódia, já enfrentada pelo Supremo Tribunal Federal em algumas oportunidades, tendo esta corte adotado posicionamentos diferentes evoluindo a jurisprudência ao longo dos anos.

O Supremo Tribunal Federal havia firmado entendimento que o princípio da presunção de inocência não configurava óbice para o início de pena privativa de liberdade após sentença condenatória. Corrobora tal entendimento, o posicionamento firmado no julgamento do Habeas Corpus n. 82.490, julgado em 2002, sob a relatoria do tão lembrado Ministro Sepúlveda Pertence, do qual se destaca que, no sentido de que a presunção constitucional da não culpabilidade, a qual leva a vedar o nome do réu no rol de culpados, não inibe, porém, a execução penal provisória da sentença condenatória sujeita a recursos despidos de efeito suspensivo, como o Especial e o Extraordinário.

Tal questão mereceu reflexão acerca da necessidade de recolhimento à prisão para recorrer, tal como era expressamente previsto pelo Código de Processo Penal (Decreto Lei n. 
3.689/1941), vindo a ser revogado apenas em 2008, com a promulgação da Lei n. 11.719. Até então, tal pressuposto recursal ainda vigorou perante os tribunais, mesmo com o advento da Constituição da República de 1988. Acerca desta temática, destaque-se posicionamento do Ministro Marco Aurélio no julgamento do Habeas Corpus n. 69.263, com publicação de acórdão em 09/10/1992, no qual se manifesta que

\footnotetext{
Impossível é ter como harmônica com a Constituição Federal a regra do Artigo 594 do Código de Processo Penal. Trata-se de extravagante pressuposto de recorribilidade que conflita mesmo com o objetivo do recurso. É contraditório exigir-se daquele que deseja recorrer e, portanto, mostra-se inconformado com o provimento condenatório que se apresente no estabelecimento penal para verdadeiro início do cumprimento da pena.
}

Assim, com o fortalecimento do princípio da presunção da inocência em âmbito constitucional e à luz desta, a Suprema Corte adotou entendimento de necessidade de trânsito em julgado de sentença penal condenatória para início de cumprimento da pena. Posicionamento consagrado pelo julgamento do HC n. 84.08/2010 com publicação de acórdão, sob a relatoria do Ministro Eros Grau, em 26/02/2010.

Acontece que, com a evolução do pensamento jurisprudencial, a Corte Constitucional brasileira adotou posicionamento novo acerca do tema. No julgamento do Habeas Corpus n. 126.292, com o voto do Relator, Ministro Teori Zavascki, decidiu o pretório Excelso que, caso uma decisão condenatória em primeira instância, for mantida em segunda, autorizado está o Estado a iniciar a execução da pena, inobstante a existência de outros recursos, tais como o Especial e o Extraordinário.

Assim, observa-se um movimento pendular na visão jurisprudencial da Suprema Corte, com o posicionamento passando da não necessidade de trânsito em julgado para início de cumprimento da pena, para a necessidade do esgotamento da tutela recursal para se cogitar a execução penal e, por fim, retornando tal movimento para a flexibilidade da presunção da inocência, não tendo o que se falar em decisão irrecorrível para inaugurar uma condenação.

Decisão recente que traz reflexos diretos no constitucionalismo contemporâneo, revestida de certo tom ativista, conforme abordado, indo de encontro do que outrora era entendido em termos de posicionamento jurisprudencial-constitucional, que fatalmente acarreta na relativização da presunção inocência. 
Uma privação da liberdade, penalidade máxima prevista no ordenamento jurídico pátrio, deve ser pautada na certeza, com respaldos na verdade real a ser indubitavelmente alcançada pela instrução processual penal, autorizando ao detentor do jus puniendi, adentrar abruptamente na liberdade de qualquer pessoa, apenas e tão somente com a absoluta certeza de culpabilidade, o que se dá apenas esgotando todas as possibilidades recursais, mantendo a presunção de inocência, íntima relação com outro princípio, o do in dubio pro reo, assim:

\begin{abstract}
O que se constata é que o princípio da presunção de inocência guarda grande proximidade com o do in dubio pro reo. Nada obstante o fato de se tratar de um direito individual, portanto destinado a proteger uma situação subjetiva, o princípio em questão não deixa de ter uma outra vertente, esta voltada para o juiz no sentido de impor ao magistrado o pronunciar-se de forma favorável ao réu, toda vez que não tiver certeza quanto aos fatos decisivos postos em controvérsias (CANOTILHO apud BASTOS; MARTINS, 1989, p. 278).
\end{abstract}

Enquanto houver uma possibilidade de recurso, haverá a possibilidade de alteração de sentença condenatória e, existindo tal chance, sobre a atuação jurisdicional reluz um fio de dúvida, que é mais do que suficiente para barrar o início de pena privativa de liberdade.

Deste modo, "o princípio da culpa é violado se, não estando o juiz convencido sobre a existência dos pressupostos de fato, pronuncia uma sentença de condenação" (CANOTILHO apud BASTOS; MARTINS, 1989, p. 278), violando nestes casos, o princípio da presunção de inocência e do in dubio pro reo que "constituem dimensão jurídica processual do princípio jurídico material da culpa concreta como suporte axiológico normativo da pena" (CANOTILHO apud BASTOS; MARTINS, 1989, p. 279).

Percebe-se, pois, uma relativização adotada pela Suprema Corte para interpretar o tão mencionado princípio da presunção da inocência, que prevê claramente que ninguém será considerado culpado, a não ser com sentença condenatória irrecorrível. Ademais, há de se frisar que, em decorrência dos princípios supracitados, importante necessariamente frisar que nulla poena sine culpa. Logo, se não há culpa, não há pena. 


\section{A RELATIVIZAÇÃO E A QUESTÃO HUMANITÁRIA DA DIGNIDADE DA PESSOA}

No âmbito do sistema jurídico nacional uma vastidão de degraus foi palmeada até que se pudesse constar num texto constitucional um abrangente e eficiente sistema de direitos e de garantias fundamentais, não querendo sugerir-se com isso que ele nunca existira no plano do constitucionalismo brasileiro; ao contrário, em todas as Cartas Políticas brasileiras, do Império à República, há um compartimento, ainda que minimamente, reservado para os direitos fundamentais.

Antes, contudo, é de se ressaltar, a Constituição de outubro de 1988 em seu frontispício consagra como um dos fundamentos da República Federativa do Brasil a dignidade da pessoa humana, preceito inerente ao ser humano, presente desde sua concepção e que deve ser observado em todos os níveis nas relações sociais (ALTAVILA, 1995, p. 4142).

Esse postulado é substancialmente o fundamento da sociedade, sem o qual não seria possível sua existência, perfazendo, sem margem para dúvidas, o elemento justificador das razões inerentes em seu âmbito de configuração. Ao encampá-lo no âmbito do direito positivado o legislador constituinte disponibilizou ao operador jurídico uma sistemática apta a garantir a harmonia do ordenamento jurídico pátrio, impedindo interpretações que levassem à subversão dos propósitos maiores do texto constitucional (REALE, 1995, p. 145-148).

Invocar o fundamento constitucional da dignidade humana pressupõe reconhecer a pessoa como ser humano diferenciado dos demais seres devido sua racionalidade e sociabilidade, devendo se desenvolver em meio apropriado para atender as suas necessidades. É reconhecer-se na pessoa sua autodeterminação em relação ao Estado e a todos os outros seres, vez que tal primado é valor extremo que traz para si o núcleo de todos os direitos fundamentais do homem.

Por sobre essa plêiade de ideias e, ademais, por ser apresentada a dignidade humana como um valor supremo e um parâmetro em que devem ser valoradas todas as demais normas de conduta estatal, se vislumbra o horizonte de ser tal princípio o pavimento pelo qual se estribam os direitos e as garantias fundamentais na ordem constitucional hodierna, congregando-se nele o ponto de partida e, ao mesmo tempo, o núcleo existencial.

Como valor intrínseco a todo ordenamento, a dignidade é algo real, irrenunciável e inalienável, uma situação material que deve ser diuturnamente observada sob o risco de ver-se anulada toda atividade estatal pautada no arbítrio e nos excessos intoleráveis dos seus agentes. 
O desrespeito à dignidade da pessoa humana constitui-se uma ferida aberta contra a própria existência do ser (ABBAGNANO, 2003, p. 276).

Os reflexos do sentido da dignidade humana pululam, na órbita judicial, na obrigatoriedade do magistrado ter em mente, antes de desenvolver sua atividade, aplicando seu convencimento, a real dimensão da necessidade de enxergar no jurisdicionado uma pessoa detentora de direitos minimamente assegurados. Destarte, esse superprincípio revela ao julgador as diretrizes nas quais opera a atividade estatal para que não se suprima a liberdade individual sem regra ou condição autorizadora, respeitando-o em sua integridade física e psíquica.

Deve-se compreender na dignidade humana sempre o paradigma em que se estribar a decisão judicial, afastando as formas discriminatórias nesta. Ao decidir sobre a aplicação da norma, decide também o julgador por parâmetros da vida do jurisdicionado. Nisso reside a afirmação de que o tratamento digno é um mandamento ético (SARLET, 1998, p. 103), acobertado pelo senso maior de justiça (LAVIÉ, 1995, p. 47-49).

Em derradeiro, a par das árduas tentativas de se atingir com amplo grau de segurança um mínimo conceito para a dignidade humana, nota-se que a aplicabilidade dos ditames oriundos deste fundamento reserva ao Poder Judiciário a árida, porém nobre, missão de servir como o atracadouro das garantias que devem ser ofertadas ao combate a qualquer espécie de violação dos direitos decorrentes daquele preceito maior.

O fato de ninguém ser considerado culpado até o trânsito em julgado de sentença penal condenatória, não significa apenas uma regra processual recursal propriamente dita, tal enunciado trazido pela Constituição da República de 1988 e repetido incessante e quase unanimemente por textos constitucionais e Cartas de direitos humanos mundo afora, conduz a uma discussão social, com valoração da pessoa.

Tal questão conduz a uma reflexão acerca da dignidade do ofendido, pois, é um fardo pesado para o cidadão ser tido como liminarmente culpado, o que poderia conduzir a um império de arbítrio e injustiça (BASTOS; MARTINS, 1989, p. 277).

Adentrar no direito à liberdade da pessoa e sujeita-lo a uma pena de prisão sem esgotar as possibilidades recursais soa de modo ofensivo à dignidade do condenado. Necessário se faz pensar na possibilidade de a sentença condenatória ser modificada perante os tribunais superiores, absolvendo o réu.

E se tal situação ocorrer? Como admitir que o Estado invada abruptamente a esfera individual, cessando a liberdade sem a devida certeza de culpabilidade? Há de se considerar, a possibilidade de um recurso a Tribunal Superior modificar a sentença, absolvendo o Réu, que 
já cumpriu parte da pena. Tal situação representa uma ofensa a própria dignidade da pessoa, uma violação à

qualidade intrínseca e distintiva reconhecida em cada ser humano que o faz merecedor do mesmo respeito e consideração por parte do Estado e da comunidade, implicando, neste sentido, um complexo de direitos e deveres fundamentais que assegurem tanto contra todo e qualquer ato de cunho degradante e desumano, venham a lhe garantir as condições existenciais mínimas para uma vida saudável, além de propiciar e promover sua participação ativa e corresponsável nos destinos da própria existência e da vida em comunhão com os demais seres humanos (SARLET, 2013, p. 126)

Com o novo posicionamento da Suprema Corte brasileira, adotado com o julgamento do Habeas Corpus n. 126.292, corre-se um sério risco de ocorrer prisões indevidas, com o Réu vindo a ser inocentado em seguida, por tribunais Superiores. Tal situação conduz um desrespeito ao próprio sistema democrático, favorecendo encarceramento indevido.

O Objeto em debate, talvez seja o bem de mais valia a ser tutelado pelo ordenamento jurídico, cessar-lhe sem uma certeza de culpabilidade não condiz com os ditames democráticos vigentes. Há que se ressaltar que os impactos sociais que são acarretados sobre um indivíduo, indevidamente preso, são quase inestimáveis, o abalo psicológico, o modo de interação com a família e até mesmo a reinserção perante a sociedade.

Percebe-se ainda, uma inversão da presunção de inocência, relativizando o seu conceito e aplicabilidade. Até decisão de segunda instância, presume que a pessoa é inocente, a partir daí, presume-se culpado, tendo que o réu provar sua inocência em sede recursal com clara inversão do ônus da prova. Ademais, a pessoa encontra-se perante o Estado, com uma situação de hipossuficiência, inclusive quando se trata de produção probatória.

Não há de se admitir um constrangimento a princípios garantidores da pessoa como liberdade e sua dignidade, sem a devida certeza de culpabilidade, o que advém com o trânsito em julgado de sentença, observado todos os meios de defesa e possibilidades recursais. 


\section{CONCLUSÃO}

A proposição nuclear do presente artigo é realizar uma análise crítica acerca da relativização da presunção de inocência, com a decisão recente do Supremo Tribunal Federal, acerca da antecipação do cumprimento da pena pendentes, ainda, recursos técnicos às instâncias superiores. O reflexo dessa decisão, as constantes tensões entre direitos fundamentais e os aspectos do constitucionalismo contemporâneo, à luz da dignidade humana e do viés democrático nacional, perfazem a problemática e os objetivos aqui propostos. Para tanto, lança-se mão do método de pesquisa analítico documental, pela dedução lógico-jurídica.

O princípio da presunção da inocência é forte característica de um Estado com viés democrático, tal como o brasileiro, a fim de fazer cessar arbitrariedades e penalidades indevidas, presenciadas no curso da história. O fato de ninguém ser considerado culpado até sentença condenatória que observe, sobretudo a ritualística processual e recursal consiste numa concretização da soberania individual, louvando a presunção da inocência.

A Suprema Corte brasileira adotou posicionamento que uma sentença condenatória mantida em segunda instância está apta a autorizar o início do cumprimento da pena, não representando esta antecipação penal, segundo a corte, enfrentamento a Constituição da República, mais notadamente à presunção de não culpabilidade.

Acontece que, o regular trâmite processual, sobretudo, ao exercício de direito recursal, pode ser interpretado como uma demora da atividade estatal, representando, como fora demonstrado, uma ineficiência do Poder Judicante aos olhos da população, que passou a desacreditar de tal Poder. A descrença está intimamente atrelada a impunidade, que representa altos índices.

Porém, como órgão Judiciário, guardião da Constituição, não cabe à Suprema Corte selar, por meio de seus julgados, políticas públicas destinadas a sanar a impunidade ou aumentar a segurança pública, com ares de satisfação à população. Tal conduta, mesmo que no exercício de função típica, representa uma mutação do entendimento constitucional, com certo viés ativista.

Não se pode olvidar ainda que, tal decisão de antecipação de início de pena, ainda que a decisão seja passível de recursos, deve ser interpretada, inevitavelmente, à luz da dignidade da pessoa humana. $\mathrm{O}$ acusado sofrer severa restrição à sua liberdade sem uma decisão definitiva, passível de modificação por meio de recursos, se faz preocupante. Há de se destacar a prisão indevida que sujeito sofre. 
Caso o réu sofra uma restrição à sua liberdade, autorizada por decisão de segunda instância e, após, Corte Superior decida de modo definitivo a questão, entendendo pela absolvição, concretizada está a inocência do réu e, este será, enfim, livre. Mas, e o período em que sofreu restrição indevida à liberdade no calvário do sistema prisional brasileiro? Caberá ao Estado apenas desculpar-se a abrir as grades da cela.

Logicamente que não se está aqui a defender, sob sólidas e irreversíveis bases, que uma condenação não tenha validade (ou legitimidade) jurídica para ser cumprida após esgotamento de 2 (duas) instâncias de análise (juízo a quo e ad quem imediato). Não é proposta da presente abordagem acender um debate acerca de um "número" de instâncias, mas, o de levar à reflexão o fato de que preceitos constitucionais pétreos (cláusulas de inamovibilidade) compõem-se de determinações abertas, carecedoras de interpretação mais favorável ao indivíduo, sob pena de se consagrar um Estado sem o viés garantista.

E brechas como essa, aberta recentemente pelo Supremo Tribunal Federal, que trata da relativização da presunção de inocência, ampliam muito o debate e os limites nos quais possa entender-se o que seja conveniente, dada a atual democracia e estágio da consolidação constitucional brasileira, no que versa acerca da minimização das garantias fundamentais em prol do atendimento de demandas midiáticas e dos reclames sociais, estes que sugerem um Estado punitivo a qualquer custo. Brechas que podem não mais serem colmatadas, manchando a alma de uma nação que se autoproclama "humanitária". 


\section{REFERÊNCIAS BIBLIOGRÁFICAS}

ABBAGNANO, Nicola. Dicionário de Filosofia. Revisão da tradução e tradução dos novos textos: Ivone Castilho Benedetti. São Paulo: Martins Fontes, 2003.

ABBOUD, Georges. Jurisdição Constitucional e direitos fundamentais. São Paulo: Revista dos Tribunais, 2011.

ACKERMAN, Bruce. Adeus, Montesquieu - Good-bye, Montesquieu. Trad.: Diego Weneck e Thomaz Henrique Junqueira de Andrade Pereira. Revista de Direito Administrativo, Rio de Janeiro, v. 265, p. 13-23, jan/abr. 2014.

ALTAVILA, Jayme de. Origem dos direitos dos povos. 6. ed. São Paulo: Ícone, 1995.

BARROSO, Luís Roberto. Judicialização, ativismo e legitimidade democrática. [Syn]Thesis, Rio de Janeiro, vol. 05, n. 01, 2012, p.23-32.

BASTOS, Celso Ribeiro; MARTINS, Ives Gandra. Comentários à Constituição do Brasil: promulgada em 05 de outubro de 1988. São Paulo: Saraiva, 1989.

BECCARIA, Cesare. Dos delitos e das penas. Trad.: Vicente Sabino Junior. São Paulo: CD, 2002.

CAPPELlETTI, Mauro; GARTH, Bryan. Acesso à justiça. Porto Alegre: Sérgio Antonio Fabris Editor, 1988.

COELHO, Inocêncio Mártires. Jurisdição Constitucional: Posição institucional, legitimidade e legitimação. Estado constitucional de Direito ou estado judicial de Direito? In: MENDES, Gilmar Ferreira; BRANCO, Paulo Gustavo Bonet. Curso de direito constitucional. 4. ed. rev. e atual. São Paulo: Saraiva, 2009.

FUNDAÇÃO GETÚlIO VARGAS SÃO PAULO. Relatório ICJBrasil, $1^{\circ}$. Trimestre/2014 $4^{\circ}$. Trimestre/2014: Ano 06.

GIACOMOLLI, José Nereu. Comentário ao artigo 5º, LVII. In: CANOTILHO, J.J. Gomes;

MENDES, Gilmar F.; SARLET, Ingo W.; STRECK, Lenio L. (coords.). Comentários á Constituição do Brasil. São Paulo: Saraiva-Almedina, 2013. p. 440-445.

GOMES. Luis Flávio. De 5\% a $8 \%$ dos homicídios são elucidados no Brasil. Revista Consultor jurídico. Ago, 2012. Disponível em: http://www.conjur.com.br/2012-ago30/coluna-lfg-homicidios-sao-elucidados-brasil. Acesso em março de 2016.

GÜNTHER, Jacobs. Tratado de direito penal: Teoria do Injusto Penal e Culpabilidade. Coord. Superv.: Luiz Moreira; Gercélia Batista de Oliveira Mendes e Geraldo de Carvalho. Belo Horizonte: Del Rey, 2008. 
HUNGRIA, Nélson. Novas questões jurídico-penais. Rio de Janeiro: Jacintho, 1940.

KELSEN, Hanz. A garantia jurisdicional da constituição. Doutrina estrangeira. Direito Público, n. 1, p. 90-130, jul-ago-set, 2003.

LAVIÉ, Humberto Quiroga. Los derechos humanos y su defensa ante la justicia. Santa Fé de Bogotá: Editorial Temis, 1995.

MENDES, Gilmar Ferreira. Direitos fundamentais de caráter judicial e garantias constitucionais do processo. In: COELHO, Inocêncio Mares; BRANCO, Paulo Gustavo Bonet. Curso de direito constitucional. 4. ed. rev. e atual. São Paulo: Saraiva, 2009.

NAGEL, Robert. Direito Político, Política legislativa: Uma história recente da Teoria da Questão Política, Tradução de Eliana Valadares Santos. In: BIGONHA, Antonio Carlos Alpino;

MOREIRA, Luiz. Limites do controle de constitucionalidade. Rio de Janeiro: Lumen Juris, 2009.

OLIVEIRA, Leandro Corrêa de. Jurisdição constitucional em perspectiva: judicialização, ativismo judicial e diálogo no Supremo Tribunal Federal. Rio de Janeiro, 2014 - Tese (Doutorado em Direito) - Universidade Estácio de Sá, 2014.

PEREZ, Fabíola. A luta por um remédio. Revista Istoé. São Paulo, ed. 2375, jun. 2015. Disponível

em:http://www.istoe.com.br/reportagens/421371_A+LUTA+POR+UM+REMEDIO. Acesso: mar. 2016.

REALE, Miguel. Lições preliminares de direito. 22. ed. São Paulo: Saraiva, 1995.

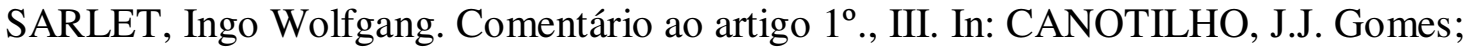

MENDES, Gilmar; STRECK, Lenio (coords.). Comentários à Constituição do Brasil. São

Paulo: Saraiva-Almedina, 2013. p. 121-128.

. A eficácia dos direitos fundamentais. Porto Alegre: Livraria do Advogado, 1998.

STRECK, Lênio. Jurisdição constitucional e decisão jurídica. 4. ed. São Paulo: Revista dos Tribunais, 2014. 